\title{
"For they did not change their language« (MekhY Pischa 5): On the Early Medieval Literary Rehebraicisation of Jewish Culture
}

\section{Constanza Cordoni*}

Following the early commentary on the book of Exodus in the Mekhilta deRabbi Yishmael (third century CE), a series of later rabbinic texts with other exegetical agendas praise the children of Israel for remaining loyal to their language identity during the time of the Egyptian bondage. This tradition is found both in Hebrew and in Hebrew-Aramaic rabbinic corpora of the classical period before it is taken up in early medieval works, for the most part written in Hebrew, which attest to a return to Hebrew in part of the Jewish literary production in the early Middle Ages. This paper is about tracing this evolving tradition through changing contexts.

\section{Keywords: Language ideology; Jewish identity; rabbinic literature}

\section{Introduction: "Hebrew for Speech" and Jewish Multilingualism}

Jewish communities of Late Antiquity and the Middle Ages, whether in the ancestral homeland in the land of Israel or in the Eastern, North African or European Diaspora spoke and/ or wrote in a number of languages which, in all likelihood, were at least to a certain extent distinct from the languages of their non-Jewish environment. With the terminology of sociolinguistic research, these can be designated as Jewish languages. ${ }^{1}$ One of these languages was Rabbinic or Mishnaic Hebrew, which, before becoming a Jewish literary language in the third century CE, had been, like Greek and Aramaic, a language spoken by Jews for centuries. ${ }^{2}$ From then onwards, whether in Roman-Byzantine Palestine or in Sasanian Persia, the

* Correspondence details: DDr. Constanza Cordoni, Department of Medieval Research, Austrian Academy of Sciences, Hollandstraße 11-13, 1020 Vienna, Austria; email: Constanza.Cordoni@oeaw.ac.at.

1 "Jewish language varieties", "Jewish linguistic repertoires « and »ewish religiolects « are further terms to describe these linguistic phenomena. See Hary and Bunin Benor, Languages in Jewish Communities, 1 . Hebrew is referred to as the "one« original language before the episode of the tower of Babel (safa achad, Gen 11:1), as "Jewish « (yehudit, 2 King 18:28; Isa 36:11, in contrast to aramit; Neh 13:24, in contrast to ashdodit), as the »language of Canaan " (sefat kenaan, Isa 19:18), in Scripture and as the holy language (leshon ha-qodesh) and Hebrew (ivrit) in rabbinic literature. See Mock, Hébreu, 43-44. Biblical Hebrew is - chronologically at least - the first of these Jewish languages. That is, as long as we do not distinguish between Hebrew and Jewish languages. See Bar-Asher, Jewish languages, 130. On the Jewish languages of medieval Europe, see Bunis and Robinson, Languages and translations. I wish to thank Günter Stemberger, Rodrigo Laham Cohen and the anonymous reviewers for their critical comments and helpful suggestions on an earlier draft of this text.

2 On Hebrew as experiencing a revival with the rabbinic movement in the third century, see de Lange, Revival of the Hebrew language. For an overview on the relationship between the Hebrew language and the other Jewish languages across history, see Bar-Asher, Jewish languages. 
Sitz im Leben of Hebrew was not in Jewish life in the broad sense of the term, given that its use was reduced to liturgy and literature. And even in these two areas, Aramaic dialects are present: the Targumim, composed both in Palestine and in Babylonia between the second and the eighth centuries CE, transferred part of the text of the Hebrew Bible into a language people could understand in a synagogal context. Although "targum " is generally rendered as »translation «, the ancient targumim are more appropriately described as an admixture of translation and commentary. Apart from these texts related to the synagogue, it is also in the sources that go back to the house of study that we find evidence of Hebrew interacting with Aramaic. The major corpora of rabbinic literature of the so-called amoraic period - texts which are generally grouped as belonging to the two major categories of rabbinic literature of the classical period, Talmud and Midrash - attest to what may be described as a written interplay of Biblical Hebrew, Mishnaic Hebrew and Aramaic (dialects). ${ }^{3}$ These texts translated, insofar as they were concerned with making relevant for the present earlier, canonical texts, expressing in a more accessible wording and with more appealing ideas norms and stories transmitted in the Mishnah, the first document of rabbinic Judaism whose redaction, according to the traditional theory, took place by the early third century, and in the Hebrew Bible. ${ }^{4}$ With different purposes, both the targumim and the rabbinic corpora are forms of exegesis that acknowledge Jewish multingualism as a phenomenon of Late Antiquity.

This phenomenon is most openly addressed in the following lines of the Palestinian Talmud (also referred to as the Yerushalmi, end of fourth-fifth century), which also describes a functional division of languages, some of them Jewish languages, in Late Antiquity:

Rabbi Jonathan of Beit Guvrin said: There are four pleasing languages of which the world makes use and these are they: [the] foreign [language] (i.e. Greek, la $a z$, לע) for song; Roman (i.e. Latin, romi, רומי (עורסי) for battle; Syrian (i.e. Aramaic, sursi lamentation, [and] Hebrew for speech (ivri le-dibbur, עברי לדיבור). And some say, also Assyrian for writing (ashuri likhtav, אשורי לכתב). Assyrian has script but no speech (i.e. is no spoken language, lashon, לשון). Hebrew has speech but no script [of its own]. They [the Israelites] chose for themselves the Assyrian script and the Hebrew language (lashon ivri, לשון עברי). (yMeg 1:11 [71b] par. ySot 7:4 [21c])

3 I use the term »interplay « following Fraade, Language mix. Fraade, against using the sociolinguistic term »diglossia« (see Bar-Asher Siegal, Diglossia in rabbinic Hebrew), due to the fact that it »derives from modern contexts in which language functions and domains can be directly observed«, distinguishes three categories of HebrewAramaic or Greek-Aramaic internal bilingualism in rabbinic literature or in inscriptions: »interpenetration«, »internal translation, " and »code-switching".

4 On the problem of dating rabbinic corpora, see Lapin, Rabbis as Romans, 39-42. In what follows, the dates given for each of the rabbinic corpora are redactional dates. On the periodisation of rabbinic literature and its genre system, see Stemberger, Einleitung in Talmud und Midrasch, 17; Stemberger, Einführung, 71-106; Alexander, Using rabbinic literature.

5 An alternative four-language divide is found in a tannaitic document which interprets Deut 33:2 as meaning that the revelation at Sinai was spoken in Hebrew, Latin, Arabic and Aramaic (half of these languages being, by the time of redaction of this document, Jewish languages). See SifDev 343 and Smelik, Rabbis, Language, and Translation, $32-36$. 
Remarkable about this text with its four-language divide ${ }^{6}$ is not only that it refers to the major vernacular of the non-Jewish majority culture, including the Roman administration, in the period and broader region in which the Yerushalmi was redacted, Greek, as »the foreign language « and assigns to it and other languages a specific communicative function. Placing Hebrew as the last language in the list and claiming that this is the language used in the Jewish world to speak, the voice that quotes Rabbi Jonathan reclaims for Hebrew the most important of these functions, but still concedes that Jews use at least Greek and Aramaic for singing and lamenting. ${ }^{7}$ Günter Stemberger observes on the choice of "Hebrew for speech «: "wirklich zum Sprechen (dibbur) im Vollsinn des Wortes eignet sich nur das Hebräische, in dem Gott am Sinai sein Zehnwort ('aseret ha-divrot) zu Israel gesprochen hat. " ${ }^{8}$ Furthermore, both the Hebrew language and the Assyrian script used to write it down are said to be of especial value with regard to Jewish linguistic identity because these were, the text claims, chosen by Israel..$^{9}$ The rabbis are depicted in this text as aware of the fact that there are multiple scripts from which the Jews of their own time could also choose. It may be the case that the original choice is presented as exemplary. ${ }^{10}$ The distinction between Hebrew language and Assyrian script is not maintained in another version of this passage transmitted in the later rabbinic commentary on the Psalms known as Midrash Tehillim (seventh-eighth century): ${ }^{11}$

6 The parallel transmitted in the exegetical commentary on the book of Esther presents the same argument but a different order: »Rabbi Nathan of Beit Guvrin said: There are four pleasing languages of which the world makes use: [the] foreign [language] (i.e. Greek, la $a z$, לע) for song; Syrian (i.e. Aramaic, sursi, סורסי) for lamentation, Hebrew (עvri, עברי) for speech, Roman (i.e. Latin, romi, רומי), and some say, also Assyrian for writing. Hebrew has speech but no script, Assyrian has script but no speech [is no spoken language]. They [the Israelites] chose for themselves the Assyrian script and the Hebrew language." (EstR 4:12)

7 Even if it is directed at Jews, the text is not about the Jewish world but the entire world: Roman, i.e. Latin, not being a Jewish language. As Smelik, Rabbis, Language, and Translation, 272, rephrases the passage: "Latin as the language of the military superpower, Rome, Greek as the language of culture, Aramaic as the vernacular of the indigenous people and Hebrew as the medium of the [rabbinic] scholars."

8 Stemberger, Hebräisch als ideale Sprache, 91.

9 See bSan 21b-22a on the Israelites choosing their language after their return from the Babylonian Exile. According to Fraade, Language mix, 9, this compromise is probably a "retrojection from a later time when Hebrew and Aramaic vied with one another (as with Greek) for cultural priority." The need to mention the Assyrian as Jewish script is given by the exegetical context: the mishnah which this passage interprets, mMeg 1:11, claims that Torah scrolls may, for the purpose of study, be written in any language (and script, e.g. in Greek) but that phylacteries and mezuzot may only be written in square (Assyrian) script.

10 In the wider context of the quoted passage, they distinguish between Palaeo-Hebrew (ra'ats, ץ ץ) and Assyrian script, but apparently also between these and Greek script. On the phenomenon of multiple competing alphabets as well as on the related script-switching, see Wagner, Script-switching between Hebrew and Arabic, 357-360. Multiscriptality is a common phenomenon in the context of Jewish inscriptions both in Europe and the Levant. See de Lange, Hebrew language, 122-132.

11 Traditionally, the compilation Midrash Tehillim is considered as having been edited between the eighth and thirteenth centuries. On the first part, i.e. MidTeh 1-118, Stemberger, Einleitung in Talmud und Midrasch, 358, points out: "Es ist sicher mit einer längeren Entwicklungszeit zu rechnen, was genauere Aussagen unmöglich macht." According to the Ma'agarim of the Academy of the Hebrew Language, this part was composed »before 1050 «. See Atzmon, Midrashic traditions, 118-119, who concludes, after a careful analysis of MidTeh 22, that the overall composition "was edited in Palestine in the same period in which the Tanhumaic midrashim were being created, and in fact should be ascribed to an intermediate period between the classic amoraic midrashim and late midrashim such as Pirqe de-Rabbi Eliezer«, i.e. he dates it to the seventh or eighth century. 
Rabbi Jonathan said: There are four languages: the Roman language (lashon romi, לשון (רומי) for battle, the Greek language (lashon yevani, לשון יוני) for song; the Persian ${ }^{12}$ language (lashon parsi, לשון פרסי) for lamentation, the Assyrian language (lashon ashurit, (לשון אשורית for prayer, in other words, you hold them safe under your shelter from contentious tongues (meriv leshonot, מריב לשונות). (Ps 31:21) (MidTeh 31:7)

In this version of Rabbi Jonathan's tradition, the "Hebrew language" and "Assyrian script" of the earlier version appear combined in the expression "Assyrian language«. The function of this language is not "speech" in general, but speech directed at God, prayer, of which psalms are the characteristic scriptural form. The fourth language is the language of the psalm that is interpreted and both, the prayer and its language, are a shelter for him who prays, as the prooftext suggests.

While Rabbi Jonathan's tradition in all of its versions apparently acknowledges Jewish multilingualism with relative ease ${ }^{13}$ other rabbinic voices may be understood as indirectly expressing a certain discontent or preoccupation with the Jewish multilinguistic situation the quoted rabbinic traditions, among others, addressed and to which other types of evidence attest. ${ }^{14}$ In the following pages I will be concerned with this preoccupation by tracing the development of a statement according to which the people of Israel not changing their language, Hebrew or the holy language, in Egypt, was read as a token of loyalty to their identity and as a choice that had an impact on their history of salvation. A corollary of this tradition would then be that multilingualism among Jews, because it is a change with respect to their one original language, means a problematic change from a single to a multiple identity.

12 Persian instead of Syrian is also the language mentioned as suitable for lamentation in two out of the five witnesses used by Joseph Tabori and Arnon Atzmon for their synoptic edition of the midrash Esther Rabbah. Persian is here more in accord than Syrian with the setting of the narrative context of the book of Esther and more specifically with the interpretation of Est 1:22 (»he [King Ahasuerus] sent letters to all the royal provinces, to every province in its own script and to every people in its own language«). See https://schechter.ac.il/midrash/esther_rabbah/.

13 And this is but one of many traditions which address Jewish multilingualism in the rabbinic corpora. On the interplay of Hebrew, Aramaic and Greek in Late Antiquity and »the very variety of linguistic expression as a subject of great significance in its own right «, see Fraade, Language mix, 6. On the theory and practice of multilingualism in early rabbinic literature, see Fraade, Language mix; Smelik, Rabbis, Language, and Translation, ch. 3.

14 The evidence for ancient Jewish society as »dynamically multilingual«, as Fraade, Language mix, 3 describes it, is of a literary, documentary, and inscriptional nature. 


\section{"They Did Not Change Their Language": The Early Rabbinic Evidence}

According to a passage transmitted in the early commentary on Deuteronomium Sifre (third century CE), he who fails to teach Torah to his children is punished with a short life. Furthermore, the teaching itself is to take place in the language of Scripture:

Teach them to your children, talking about them (Deut 11:19): to your sons and not to your daughters - words of Rabbi Jose ben 'Akiba. Hence the sages said: When a child begins to speak, his father should speak to him in the holy language (bileshon ha-qodesh, בלשון הקודש) and teach him Torah; and if he does not do so, it is as if he had buried him, for it is written, Teach them to your children, talking about them (ibid). If you teach them to your children, talking about them (ibid.), your days and the days of your children may be multiplied (Deut 11:21) - and if not, your days will be shortened, for so are the words of Torah expounded: the positive implies the negative, and the negative implies the positive. (SifDev 46)

Jews are to teach their sons, though not their daughters, to speak the »holy language« as soon as they begin to speak. In this world knowledge of Hebrew is understood as a precondition for the study of Torah. ${ }^{15}$ It is through speaking that the tuition takes place and the passage of this commentary, written entirely in Hebrew, suggests that the talk about Torah should likewise take place in Hebrew. For a father who fails to speak to his son in Hebrew is comparable to a filicide. ${ }^{16}$

Less intimidating is the tone of a passage in another early rabbinic commentary with its somehow similar linguistic wishful thinking. In the Mekhilta deRabbi Yishmael (third century CE) on the book of Exodus we read:

Rabbi Eleazar Ha-Qappar says: Did Israel not have four commandments (arba' mitsvot, ארבע מצות) of which the entire world is not worth? - They were not suspected of improper conduct and they were not suspected of slander (lit. »bad language, "lashon ha-ra, לשון הרע), they did not change their name (lo shinu et shemam, ולאו את שמם), and they did not change their language (ve-lo shinu et leshonam, ולא שנו את לשונם)? (MekhY Pischa 5)

15 As Stemberger, Hebräisch als ideale Sprache, points out, being able to speak Hebrew is also said to enable participation in the world to come. See yShab 1,3 (3c). See Bar-Asher, Jewish languages, 127, on boys alone learning to read Hebrew. On women being knowledgeable about Hebrew, see Ilan, Women quoting scripture.

16 Elsewhere in the same commentary we find loyalty to the language linked to loyalty to the ancestral homeland. Both are preconditions for being worthy of the world to come: "Rabbi Meir used to say: All who dwell in the Land of Israel, the Land of Israel atones for them, for it is written, the people who live there will be forgiven their iniquity (Isa 33:24). ... And so Rabbi Meir used to say: He who lives in the Land of Israel, recites the Shema in the morning and in the evening, and speaks in the holy language, see, he is a son of the world to come." (SifDev 333) On this tradition, see de Lange, Revival of the Hebrew language, 348-349. In yet another exegetical context of the same commentary, SifDev 303, it is claimed that the prayer said by the Israelite once he has set aside a tenth of his produce for the poor (Deut 26:14-15), should be said in "any language«, i.e. no matter in which language. Fraade, Language mix, 5-6, points out that the admonitions to cultivate Hebrew in these passages may either »attest to its practice or to countervailing pressures that militated against its practice.« 
The quoted passage, transmitted in the context of an interpretation of Exod 12:6, is for the most part a rhetorical question which is followed by expositions on each of four commandments implied in the question. A rabbi assumed to have been active in the land of Israel in the second half of the second century ${ }^{17}$ argues that before the Exodus Israel had four weighty commandments. ${ }^{18}$ These are collectively described with a characteristic hyperbole - they surpass the entire world in worth. Refraining from intermarriage (marriage with nonJews), from speaking ill of fellow Jews, keeping their ethnonym and language - the observance of these four commandments listed by the second-century rabbi as valid for Israel's time in Egypt contributes in later times, the redactors of the Mekhilta suggest in including this tradition in their commentary, to the preservation of Jewish identity in the Diaspora. ${ }^{19}$

The last of these commandments is of special interest for us: they did not change their language, whereby lashon is the last expression in an enumeration that makes conspicuous use of Hebrew alliteration. Later on in this commentary it is claimed that the evidence that they spoke Hebrew when they were in Egypt is found in Exod 2:14:

Whence do we know that they did not replace their language (she-lo chalefu leshonam, שלא חלפו לשונם It is said, Who made you a ruler and judge over us? (Exod 2:14) Hence [we know] that they would speak Hebrew (ivrit, עברית). For it is said, it is my own mouth that speaks to you (Gen 45:12). And it [Scripture] says, Then they said, 'The God of the Hebrews (ivryim, עברים) [has revealed himself to us'] etc. (Exod 5:3); Then one who had escaped [came and told Abram the Hebrew (ha-ivri, העברי)] etc. (Gen 14:13) (MekhY Pischa 5) ${ }^{20}$

According to Exod 2:13, Moses asks a man described with the ethnonym "Hebrew«, "Why do you strike your fellow Hebrew? « and the latter answers with the first of the verses adduced in the quoted passage. The midrash derives from this that the language in which Moses and the »Hebrew « spoke was the language Hebrew, implying that this was distinct from the language of Egyptians such as the one Moses killed but with whom he exchanged no words. ${ }^{21}$ Two of the other verses associate the language with the name of the people, while Gen 45:12 appears to link the Israelites' language to the idiom in which God speaks to them, even though in Scripture it is Joseph who speaks these words.

17 He is associated with the fourth tannaitic generation (160-200 CE). See Stemberger, Einleitung in Talmud und Midrasch, 96.

18 Against a statement by Rabbi Mattia ben Cheresh (late first - early second century CE, according to which, before they received the Torah, the Israelites had only two commandments which they could observe and on this account be worthy of redemption: the commandments of the Pesach and the circumcision.

19 See Stemberger, Mekhilta de-Rabbi Jishma'el, 460.

20 Translation follows MS Oxford, Bodleian Library, 151 (Ma'agarim).

21 The midrash cannot know for certain whether the Hebrew language these two men spoke was the Hebrew in which Exod 2 is transmitted, nor can we ascertain whether the midrash may not mean with "Hebrew « one of the Jewish Aramaic dialects which were also perceived as the language of the Hebrews in the Jewish literature of the Second Temple period and in the New Testament (on the latter see Beattie and Davies, What does Hebrew mean.) On the ultra-orthodox notion that Yiddish was the language of the Hebrews, see Silber, Emergence of ultra-orthodoxy. 
The praise of Israel's loyalty to its linguistic identity in biblical times - a sweeping praise for Jewish attachment to the Hebrew language in other times - is delivered in the context of a rabbinic document that was redacted entirely in Rabbinic Hebrew at a time when this Hebrew was waning as a spoken language. ${ }^{22}$ What is more, the same statement in Rabbinic Hebrew reappears in a number of later contexts which adapt the early tradition to their own exegetical agendas and changed cultural and linguistic contexts.

\section{"They Did Not Change Their Language«: The Evidence of Amoraic Corpora}

Characteristic for the later, amoraic corpora of rabbinic literature (literature which was redacted between the fifth and the seventh centuries but which presents material associated with rabbis who lived from the third century, in Palestine until the second half of the fourth century and in Babylonia until the end of the fifth) is the use of biblical and earlier rabbinic Hebrew materials intermingled with either Galilean or Babylonian Aramaic. ${ }^{23}$ Our statement praising the people of Israel for having refrained from changing their language in Egypt is transmitted in three roughly contemporary midrashic corpora assumed to have emerged in Byzantine Palestine in a time when Christianity had already established itself as the official religion of the Roman Empire, Aramaic and Greek were the main vernaculars of the region, liturgical poetry in Hebrew flourished, ${ }^{24}$ Aramaic Targumim paraphrased the Torah readings in the synagogue, and some Jews debated on the language in which Scripture should be read in the synagogue or the Shema recited. ${ }^{25}$

22 While scholars agree that during the tannaitic period, i.e. the time in which the sages quoted in the Mekhilta were active, Rabbinic or Mishnaic Hebrew was spoken, this does not appear to have been the case in the later (so called amoraic) period, when the Mekhilta was eventually redacted. On the question of whether Rabbinic Hebrew represented a living language, see Sáenz-Badillos, History of the Hebrew Language, 161-163. See also Fassberg, What Semitic language. It should be noted that I am not concerned here with the question of which language was "the" dominant Jewish vernacular when, that is to say, it is not my target to extrapolate from rabbinic texts on the broader Jewish society in whose midst these texts emerged.

23 See Lapin, Rabbis as Romans, 41-42, especially for the distinction between the time of the sages and the redactional dates of the corpora in which they feature. For an overview on the so called amoraic corpora of this period see Stemberger, Einleitung in Talmud und Midrasch, 306-328.

24 Although Yose ben Yose is usually dated to the fourth century and de Lange, Revival of the Hebrew language, 356, posits that a beginning of Hebrew hymnography may be envisaged in the third century, scholars of Hebrew liturgical poetry generally date the emergence of this Jewish literary genre to the sixth century. For an overview, see Weinberger, Jewish Hymnography; van Bekkum, Hebrew liturgical poetry; on the language of the liturgical poets, see Sáenz-Badillos, History of the Hebrew Language, 209-214.

25 Justinian's Novella 146 »On the Hebrews« suggests this. According to rabbinic tradition, while the reading is exclusively in Hebrew, the purpose of the targumim which were recited rather than read was to rephrase the Torah reading in Aramaic. Scholars disagree on whether the emperor reacts to real strife among Jewish parties somewhere in the Roman Empire or this is only a purported rescript to a fiction: After describing two parties among the Jews, those who consider it only proper that Scripture be read in Hebrew and those who accept Greek, the novella allows "those Jews who so wish " to read Scripture either in Greek or in any other language. Apart from fostering the use of Greek, the novel forbids the use of Jewish deuterosis. See Rutgers, Justinian's Novella 146; de Lange, Hebraists and Hellenists, and the literature cited therein. 
Probably the earliest of the amoraic midrash compilations that makes use of our statement is the homiletical midrash Wayiqra Rabbah (fifth-sixth century) on the book of Leviticus. ${ }^{26}$ To begin with, the new scriptural occasion of the commentary determines a changed hermeneutic accent: in order to expound on the base or lemma verse Lev 24:10, the midrash historicises a verse from the Song of Songs and quotes several rabbinic authorities who claim that the "garden locked « of Song 4:12 is a metaphor for Israel's chaste behaviour in Egypt. ${ }^{27}$ According to these sages, it is because of the Israelites' sexual morality during the time of the Egyptian enslavement that they were redeemed with the Exodus. However, another sage is then quoted as relativising this claim:

Rabbi Huna said in the name of Bar Qappara: Israel were redeemed from Egypt on account of four things (arba' devarim, ארבעה דברים): Because they did not change their name and [because] they did not change their language, because they did not utter slander, and because none of them was of improper conduct. (WayR 32:5)

The fourth-century sage Huna claims ${ }^{28}$ that it is not for one but for four reasons that the people of Israel were rewarded with leaving Egypt, the last to be mentioned being their chastity - hereby the reference to an intermarriage in Lev 24:10 is understood as the exception that proves the rule. Whereas keeping their language is mentioned last in the list of the Mekhilt aand therefore accorded a prominent place in the list, it is only the second item in this amoraic midrash, which is evidently more concerned with the challenge posed to Jewish identity by the Israelites' failure to cope with standards of sexual morality than with their not sticking by a monolinguistic commitment to the Hebrew language. ${ }^{29}$ Unlike the context in that early midrash compilation, ${ }^{30}$ the claim in Hebrew that the people of Israel did not change their language in Egypt is now found in a bilingual rabbinic document that not only switches between Aramaic and Hebrew, but may even be regarded as an Aramaic text. ${ }^{31}$ Furthermore, the new hermeneutic context of Wayiqra Rabbah is more explicit than the earlier parallel in the Mekhilta as to Greek as a language that competed with the original one, the language of the time before the Exodus..$^{32}$ The passage quoted below in particular addresses an ethnolinguistic discontent pertaining to the use of Greek names. The expansion of the first of the four praiseworthy deeds previously mentioned reads:

26 On Wayiqra Rabbah see Stemberger, Einleitung in Talmud und Midrasch, 319-323; Samely, Literary structures; Neusner, Leviticus in Leviticus Rabbah.

27 As part of its historisicing interpretation of the Song of Songs which links it to the Exodus, the early commentary on the book of Exodus made use of verses such as Lev 24:10 and Song 4:12, which, in these later commentaries, provide the hermeneutic occasion for the exegetical exposition. On the development of the historicising reading of the Song of Songs, see Stemberger, Midrashim zum Hohenlied.

28 The Eleazar ha-Qappar, in whose name the statement is quoted in the Mekhilta, is probably Bar Qappara's father. See Stemberger, Einleitung in Talmud und Midrasch, 96.

29 The same is true of the close parallel transmitted in the commentary on the Song of Songs. See ShirR 4:12:1.

30 With which Wayiqra Rabbah shares the scriptural evidence in Gen 14:13; Exod 5:3; Gen 45;12 that the Israelites went on using their own language in Egypt.

31 As Bar-Asher, Jewish languages, 130, argues, it is not the number of words in one or the other language which determines which a text's language actually is. Similarly, Fraade, Language mix, 24-25. In the case of Wayiqra Rab$b a h$, as in the rest of the commentaries of this period, Hebrew (both Biblical and Rabbinic) features prominently, but the document itself is not a Hebrew one.

32 On rabbinic attitudes toward Greek, see Sperber, Rabbinic knowledge of Greek. 
"Because they did not change their name« - [those] who went down (Aram. nachatin, ניקתין) [as] Reuben and Simeon, [as] Reuben and Simeon they came up (Aram. salaqin, סלקין). They would not call Reuben Rupus (Rufus) nor Judah Luliani (Julianus?) nor Joseph Lestis, nor Benjamin Alexandri. (WayR 32:5)

While it was probably not an urgent matter to react to Hellenising Jews among the intended audience of the Mekhilta, ${ }^{33}$ the redactors of the later Wayiqra Rabbah do make a point of reminding other (rabbinic/nonrabbinic?) Jews that Hebrew names are more suitable for them. ${ }^{34}$ Apart from the impact of time on the ideology of this tradition, the difference for the two approaches could also be related to the different standard genre categorisation, and then rather to the Sitz in literature than the Sitz im Leben, of the Mekhilta and the Wayiqra Rabbah as "exegetical midrash" and "homiletical midrash" respectively. However, it is important to bear in mind that neither does the early Mekhilta have an exclusively exegetical agenda but also a political-homiletical one, nor does Wayiqra Rabbah transmit authentic homilies in which real rabbinic or non-rabbinic audiences were admonished.

The statement is found again in the later commentary on the Song of Songs Shir haShirim Rabbah (sixth century) in a passage whose thrust is still a praise of Israel's chaste behaviour while in Egypt. However, because for this passage Shir ha-Shirim Rabbah follows not only the one in Wayiqra Rabbah discussed above but especially a chapter in Pesiqta de Rav Kahana (fifth century), a midrash compilation arranged according to the liturgical year, ${ }^{35}$ new accents may be identified. The chapter in Pesiqta de Rav Kahana which Shir ha-Shirim Rabbah uses for its exegesis of Song 4:12 has its liturgical occasion in the Torah reading for the seventh day of Passover, namely Exod 13:17-18. ${ }^{36}$ Among the new arguments in whose context our statement is now found are some related to the link between ethnic identity during the time of the Egyptian enslavement, lineage and language.

Thus, to explain the expressions »a garden locked« and »my sister, my bride« in Song 4:12, Shir ha-Shirim Rabbah tells a king parable, ${ }^{37}$ according to which a king with two unmarried daughters leaves them for a long time when he goes to a distant province overseas; during his absence they both decide to marry and do so properly, ${ }^{38}$ but their actions cause people to gossip about them. Upon his return the king confronts his daughters, and after hearing from them that they have married and from his sons-in-law that they admit to having married

33 The earlier Mekhilta text did not include any Greek names to prove that the Israelites went on using the original, biblical names they had used before going down to Egypt. It operates by adducing scriptural verses that make reference to the names of the tribes (Num 1:18) and the patriarchs (Gen 48:16).

34 On the use among Jews of Greek and Latin names in late ancient Palestine, see Ilan, Lexicon of Jewish Names. There is evidence of some rabbis, at least, using names such as Alexandri, Luliani, Philipi, and even Romanos. See below for a Rabbi Marinus. Many more Greek, including even theophoric, names are attested to in contemporary Palestinian synagogue inscriptions. I thank Prof. Günter Stemberger for this remark.

35 While the Shir ha-Shirim Rabbah is, like Mekhilta deRabbi Yishmael and Wayiqra Rabbah, organised following the structure of a biblical book, the Pesigta is ostensibly organised according to a different principle. Its 28 chapters are thematic discourses that follow the synagogal readings for holy days, special Sabbaths or festivals throughout the liturgical calendar. On PesK see Neusner, Pesiqta deRab Kahana; Atzmon, Original order.

36 See PesK 11:6.

37 On the rabbinic genre of the king parable, see Appelbaum, Rabbis' King-Parables.

38 Evidence of which is their having taken from their husbands "signature and seal«. 
them, he decides he should punish the latter for having wronged his two daughters. The application of this parable to the theological message the commentary seeks to convey amounts to dismissing the idea that the Israelites, especially their women, could have been unchaste in Egypt so that their offspring be considered of mixed lineage, that is to say, in part Egyptian. ${ }^{39}$ So how does the commentary solve this conundrum?

Rabbi Pinchas said: At that time God summoned the angel who was appointed with conception and said, Go forth and form them with all the features of their fathers. And whom did their fathers themselves resemble? The founders of the families, this is what is written: for Reuben, the families of the Reubenite(s) (Num 26:7).

Rabbi Hoshaiah said: [From] Reuben, the Reubenite (ha-reubeni, הראובני); [from] Simeon, the Simeonite (ha-shimeoni, השמעוני). Said Rabbi Marinus beRabbi Hoshaia: But this is not different from such expressions as Baronite, Sabronite, Sikuyite (barony, sabrony, sikuy, ${ }^{40}$ ברוני סברוני סיכוי). Rabbi Huna in the name of Rabbi Idi [explained]: There is a he (ה) at the beginning of each name of a family and a yod (') at the end: [God (Yah, יה) $]^{41}$ testifies of them that they were sons of their fathers. (ShirR 4:12:1)

The midrash resorts to a rabbinic fantasy in the name of a sage of the fourth century: on the one hand, an angel is said to have ensured that physiognomy allowed for no uncertainty concerning the fatherhood of the Israelites. On the other, the very use of family names such as the Reubenite and the Simeonite is seen as evidence of the Israelite fatherhood of Israelites. Moreover, in his reaction against Rabbi Marinus (Latin name) ${ }^{42}$, Rabbi Huna - the same sage who later on is accredited with the statement on the Israelites' language loyalty - explains that these names differ from those of non-Jews such as Baronite ${ }^{43}$ and the like in that they have a theophoric element. The orthography of scriptural patronimics thus testifies to the purity of the male line of Israelite lineage. The Israelites have names of their own which they did not change and in their names there is a godly testimony that they had always been chaste.

39 PesK 11:6 reads: "Similarly, the nations of the world would taunt the Israelites saying to them that they are children of the Egyptians, who ruled the lives of the Israelites, all the more so their wives. "ShirR 4:12:1 reads: "Similarly, the nations of the world used to taunt (מונין) Israel saying, The Egyptians became ruthless in imposing tasks on the Israelites (Exod 1:13). If they [could force] their work, they must have subdued their bodies and wives. At that time the Holy blessed be He, said, A garden shut up is my sister, my bride (Song 4:12)."

40 MS Vat 76 reads sikuy, סיכויי, MS Oxford 102 soko, סוכו, MS Munich 50 sinuy, Oינוי סבוני.

41 According to Tamar Kadari's synopsis of ShirR, only two out of five textual witnesses with this statement read Yah, יה. The rest of the witnesses leave the syntactic subject implied. See https://schechter.ac.il/midrash/shir-hashirim-raba/.

42 See Ilan, Lexicon of Jewish Names, 285-287.

43 This list of three seemingly non-Jewish names is a unique occurrence in rabbinic literature. 
It is also in the medieval Midrash Tehillim that our four-merit statement is transmitted in slightly modified wording, ${ }^{44}$ with new scriptural material, and again, as in the Mekhilta, in the name of Eleazar bar Qappara. The exegetical occasion for praising the people of Israel for having adhered to their language is, in this case, the interpretation of psalm verses ${ }^{45}$ which precisely describe the Exodus as liberation from a foreign linguistic environment:

"They did not change their language«: for they used to speak (hayu mesapperin, היו (מספרין the holy language, for it is said, the house of Jacob from a people of strange language, Judah became His sanctuary (Ps 114:1-2): for His holy language (lileshon haqodesh shelo, ללשון הקודש שלו). (MidTeh 114:4)

The language that the ancestors of the Jews spoke while in Egypt was undoubtedly the holy language, the midrash assumes. Moreover, there is a linguistic aspect to the redemption of the Exodus: leaving Egypt is read here as an affirmation by Israel of its commitment to the holy language and its correlated entry into a space-time of holy language. Considering that Midrash Tehillim as an overall composition was probably redacted in Palestine under early Muslim rule, it may be seen as a praise of Hebrew in a changed diasporic context.

A statement first attributed to a tannaitic sage, according to which not changing their language was one of four things the people of Israel did for which they deserved to be saved from Egypt and which, as Willem Smelik observes, is the very reason why »the Israelites retained their identity ... despite the Egyptian environment in which they lived " ${ }^{47}$, is transmitted as part of the exegesis of Lev 24:10; Exod 13:17-18; Song 4:12; and Ps 114:4 in several amoraic corpora. Originally cited in the Mekhilta in the name of Rabbi Eleazar Ha-Qappar, the statement is quoted in the amoraic midrash compilations Wayiqra Rabbah, Pesiqta de Rav Kahana, Shir ha-Shirim Rabbah, and Midrash Tehillim in a different order (language loyalty does not appear to be the main issue), in the name of two sages that now build a small chain of transmission, each time with a slightly different hermeneutic exigencies.

\section{Hebrew for Writing: Redemption in Written Hebrew}

When we turn to other works of the early medieval period, we find a quite interesting passage, according to which the Israelites did adopt a language other than their original one and identified with this other language to such an extent that even God used this language to communicate with them. According to a midrash of Exod 20:2, the holy language was, for a moment at least, an idiom other than Hebrew, i.e. a language which the midrash takes to be non-Hebrew: ${ }^{48}$

44 While MekhY, WayR, PesK, and ShirR praise Israel for not having uttered slander, MidTeh describes them as not having revealed their secret (ולא גילו את מסתורין שלהם).

45 On foreignness as related to language in the Hebrew Bible, see Deut 28:49; Isa 33:19; Jer 5:15.

46 The words that follow after the psalm quotation are transmitted in MS Cambridge, UB Or. 786, the basis for Buber's edition quoted in the appendix, but not in several other textual witnesses. It looks as if the copyist of this one manuscript would have inserted an explanatory gloss. I thank Günter Stemberger for calling my attention to this.

47 Smelik, Rabbis, Language, and Translation, 43.

48 On languages other than Hebrew as the holy tongue, see Smelik, Rabbis, Language, and Translation, ch. 2. 
Rabbi Judah said: This term (lashon zeh, לשון) I זהכי (Exod 20:2), is but an expression of love (leshon ahavah, לשון אהבה), an expression of affection (leshon chivah, לשון חיבה (ל) It is like a king who sent his son away to a province overseas and he learnt the language of the children of [this] overseas [province] (leshon bnei ha-yam, לשון בני הים and when he came [back] from the province overseas, his father began to speak with him in his [the son's] language (bileshono, בלשונו). Similarly, because Israel were in the land of Egypt, they learned the language of the Egyptians (leshon ha-mitsriyim, and when they came before the Holy One, the Holy One began to speak to them in their language [that they had acquired in Egypt]: I ('anokhy, (Exod 20:2) [is] there 'anokh. (PesR 21:31) ${ }^{49}$

The quoted passage is part of a homily transmitted in the midrash compilation Pesiqta Rabbati (twelfth/thirteenth century). ${ }^{50}$ According to this interpretation - which calls attention to the proximity of Hebrew 'anokhy to Coptic 'anokh - it is because the Israelites did change their language, that God, compared to a loving father, allegedly started his speech in Exod 20 with this "barbarism «. ${ }^{51}$

However, the statement on the Israelites' loyalty to their language did not die out with the amoraic sources, but was still found appealing in post-amoraic literature. It remained a Western rabbinic tradition and did not make its way into the Babylonian Talmud. Characteristic for the post-amoraic midrashim assumed to have been redacted in the period following upon the Arab conquest and during the time when the associated Arabicisation of Jewish culture was taking place in the Near East is that they almost completely abandon the use of Aramaic and return to the monolinguistic Hebrew form of expression of earlier, tannaitic compilations. ${ }^{22}$ Some scholars have even posited that these works show a return to forms of biblical Hebrew. In two such works our statement returns and now it is no longer a four-item list. In Pirqe de-Rabbi Eliezer, a pseudepigraphic text assumed to have been composed in the eighth century in Palestine, but which cannot be dated or localised with any precision, we read at the close of a chapter on the Egyptian enslavement:

49 The translation is based on Ulmer, Bilingual Edition of Pesiqta Rabbati.

50 On the stages in the development of the text of Pesiqta Rabbati and the date of redaction, see Ulmer, Bilingual Edition of Pesiqta Rabbati, 28-29.

51 Interestingly, according to a midrash on Exod 20:1 transmitted in Pesiqta de Rav Kahana, which was probably known to the redactor of Pesiqta Rabbati, the king to whom God is compared speaks not his son's language but that of his son's captors. God is said to have spoken the Egyptian language (lashon mitsry, לשון מצרי) in the interpreted verse. See PesRK 12.

52 In what became the realm of Islam, where Hebrew was relegated to the reading of Scripture in the synagogue and prayer, and Arabic became the Jewish language of life and a major language of literature, the Egyptian-born Saadya Gaon, expressed his concern about the degeneration of the Hebrew language in his Egron. He explains his motives for writing this work of Hebrew linguistics in the Judeo-Arabic second edition of the work! See Brody, Sa'adya Gaon, 79-84. 
Because of three things Israel went forth from Egypt: $:^{53}$ Because they did not change their language (hechelifu leshonam, החליפו לשונם) and [because] there was no slander among them, and [because of their faith] in the unity of the Name. And Israel went forth from Egypt full of all good things according to the blessings, as He remembered the word which was said to Abraham, but I will bring judgement on the nation that they serve, and afterwards they shall come out with great possessions. (Gen 15:14) (PRE 48)

It is again as a reward for having adhered to their language that the Israelites were saved from Egypt. Such a linguistic loyalty is, in this case, associated with the people's respect for each other and with their faith in the one God, on whose "word" (dibbur/davar), as is stated earlier in the same chapter, the world stands ${ }^{54}$ - but not with the people's sexual morality.

All the more terse is the statement in another late midrashic work, Seder Eliyahu, similarly obscure when it comes to determining its date and place of composition, though, according to present scholarly consensus, it might have been composed in the first half of the ninth century.$^{55}$ In the context of a homiletical-ethical discourse, ${ }^{56}$ another Song of Songs verse is adduced, this time to describe the Israelites' exemplary conduct while they were in Egypt:

Another interpretation: at the crown with which [his mother ('imo, אמו )] crowned (ba-'atarah she-iterah, בעטרה שעיטרה) (Song 3:11): When Israel were in the desert they did not change their name and their language (lo shinu shemam u-leshonam, שינו (שמם ולשונם and the ministering angels would murmur behind them and say, Definitely there are among them, among those ones [some whose deeds are] like the deed[s] of Abraham, Isaac, and Jacob. Therefore it is said: They did not change their name and their language. (SER 17)

In the quoted passage, a midrash on Song 3:11, the anonymous authorial voice of Seder Eliyahu explains the apparently redundant wording of the verse - which uses two word forms of the same root adjacently - by means of a minimal version of our statement. Reduced to two items, it is now used to argue that the generation of the desert distinguished themselves by a double maternal crown: not changing their name and language are praiseworthy decisions of the Israelites, even if such a conduct may have been predicated only on a few who were then compared with the patriarchs. The author of Seder Eliyahu counts himself among the few of his own generation who, in composing this very work in Hebrew, contributed to the continuity of a Jewish linguistic identity to which some among the Israelites in Egypt also contributed.

53 Bamidbar Rabbah I, a European medieval midrash (thirteenth century, Provence), has a list of three items in an identification of the three types of burnt offering mentioned in Num 7:45 as the »three good characteristics « (middot tovot, מידות טובות) by virtue of which they were delivered: »they did not change their name, they did not change their language, and they guarded themselves against improper conduct.« (BamR 13:20)

54 It must be noted that PRE 48 addresses the problem posed by the son issued from the union of an Israelite woman and an Egyptian: the Egyptians rape Shelomith after killing her husband Bedijah of the tribe of Dan. In accord with his bitter conception, the behaviour of Shelomith's son is described as bitter. PRE's attitude towards chastity appears to be even more stringent than that conveyed in the earlier midrashic compilations.

55 For a survey on the research on the date and place of composition of Seder Eliyahu, see Cordoni, Seder Eliyahu.

56 This expands on a mishnah from tractate Avot (3:9), a tractate which features quite prominently in Seder Eliyahu and which is considered in its extant form as late. See Stemberger, Mischna Avot. 
These two works of later rabbinic literature appear to be more intent than their earlier counterparts on their celebration of the Jews' linguistic constancy: first of all, in that they reduce the list to three and two items respectively, whereby adherence to language is placed in a more prominent position than in the amoraic documents. Second, unlike all the earlier midrashic compilations, they do not expand on each of these items with additional arguments, so that neither are scriptural verses adduced to prove the statement, nor is it specified that the language the Israelites continued to be loyal to is Hebrew nor, and probably more important still, do these texts point out that the Israelites went on speaking the language as, for example, in the Mekhilta (see above). This is probably not incidental, for it is a written return to Hebrew as mode of midrashic expression that these texts are concerned with.

\section{Rehebraicisation: External and Internal Evidence}

In two articles from the year 1996 Nicholas de Lange addressed the question of a late ancient and early medieval Jewish commitment to the Hebrew language. In one piece he focused on what he described as a revival of Hebrew in the Land of Israel in the third century as evidenced by the language of the tannaitic corpora, the Hebrew inscriptions in Bet She arim and statements by Origenes pertaining to Aquila's translation, among other sources. ${ }^{57} \mathrm{In}$ the second piece he provided a survey of the evidence of knowledge and use of Hebrew among Jews in Europe before the eleventh century, when Hebrew had established itself as the European Jewish language of literacy, literature, and worship, comparable to Latin for Christians in the West. ${ }^{5}$ He discussed there three types of evidence: scattered allusions to the languages used by Jews in Christian literary sources (fifth-ninth century), ${ }^{59}$ a legal text (mid-sixth century) - in both cases external evidence - and multilingual or Hebrew inscriptions (ninth century ${ }^{60}$

- tokens of internal evidence. He concludes that it is from the ninth century - centuries after Justinian's Novella 146 »On the Hebrews« documents an inner-Jewish dispute about the language to be used for the reading of Scripture in the synagogue ${ }^{61}$ - that "the first evidence

57 De Lange, Revival of the Hebrew language.

58 De Lange, Hebrew language, 113: "from the eleventh century on we have reliable evidence from many different parts of Europe that Hebrew was used as a language - perhaps even the only language - of 'high' culture among Jews. [...] By this time it would seem that Hebrew was the only language that Jews normally learned to read and write, and it would be reasonable to assume that it was the usual language of synagogue worship and Bible reading in most if not all European Jewish communities. Its use was thus in many ways analogous to that of Latin by western Christians.«

59 In this connection de Lange, Hebrew language, 118-121, discussed references to knowledge of Hebrew during the renaissance of the ninth century and concluded "that there is some confirmation from the Carolingian empire of the phenomenon directly attested in South Italy at this time, namely a use of Hebrew by Jews for scholarly purposes", as an example of which he mentioned the chronicle Josippon, the medical writings of Shabbetai Donnolo and the liturgical poets Silano and Shephatya. On Josippon, see Dönitz, Historiography among Byzantine Jews; on Italian piyyut, see Hollender in Reif and Hollender, Liturgy and Piyut, 664-669, who also mentions the paytan Amittai.

60 Hebrew features especially prominently in inscriptions from southern Italy.

61 De Lange, Hebraists and Hellenists, 221-222, describes the two parties the novella implies as traditionalists and innovators, whereby the latter would be the Hebraicising faction. However, he points out that "some have seen the Hebrew faction as the custodians of tradition, resisting an attempt by Hellenizers to replace the Hebrew language by Greek." (221) In his view the document attests to a "general trend of replacement of Greek by Hebrew « in the realm of Byzantium and to the fact that the emperor sided with the traditionalist, Hellenised Jews, suppressing the movement at an early stage, given the centuries-long silence on the matter. 
for a real familiarity with the Hebrew language and Hebrew literature « can be ascertained, even if this evidence is limited both in scope and location. ${ }^{62}$ De Lange closes his survey cautiously endorsing the view that a "pro-Hebrew pressure in Europe « may have emanated from the rabbinic authorities of the Land of Israel rather than from those of Babylonia. ${ }^{63}$ Explicit evidence of a link between southern Italy and the Land is found in the eleventh-century Chronicle of Achima' ats. ${ }^{64}$

Less explicit about such a connection are the works of a genre which scholars consider a Palestinian phenomenon that wandered towards Byzantine southern Italy and thence to Europe and which constitutes earlier internal Jewish evidence as to the fact that Hebrew regained the status of dominant literary language among Jews between the seventh and the ninth centuries: major examples of the genre of late midrash are, besides Pirqe de-Rabbi Eliezer, Seder Eliyahu - with which we closed our survey in the previous section -, the late stratum of the Tanchuma-Yelamdenu literature, Aggadat Bereshit and several other texts of smaller scope. ${ }^{65}$ Characteristic for this post-classical rabbinic (or rabbinically oriented) genre is that it produced works in Hebrew ${ }^{66}$ at the crossroads between Late Antiquity and the Middle Ages, between collective and individual literature, and between Muslim Palestine and Christian Byzantium. The floruit of liturgical Hebrew poetry in the sixth century ${ }^{67}$ and a renaissance of Hebrew apocalyptic literature in the seventh through ninth centuries ${ }^{68}$ may also be mentioned as evidence of a choice of Hebrew as the (almost) exclusive mode of expression in certain areas of the Jewish literary genre-system. ${ }^{69}$

This article has been concerned with the examination of a tradition on the Israelites not changing their language in Egypt transmitted in texts that stem from collective corpora whose Jewish authors are associated with the rabbinic movement that became institutionalised by the third century CE in the Roman province of Palestine. ${ }^{70}$ Building upon de Lange's

62 De Lange, Hebrew language, 134-135. See also Simonsohn, Hebrew revival.

63 De Lange, Hebrew language, 136-137. See also de Lange, Hebraists and Hellenists, 217.

64 See Bonfil, History and Folklore.

65 For an overview, see Stemberger, Einleitung in Talmud und Midrasch, 345-348, 358-388.

66 The bulk of Tanchuma-Yelamdenu literature is also transmitted in Hebrew. See Weiss, Pious Irreverence, 12, for a brief description of the evolution of the corpus. Already the second layer or stratum avoids »Galilean Aramaic wherever possible, replacing it with Hebrew." As to Midrash Tehillim, while it does contain a layer of classical midrash with the Aramaic component this is bound to imply, a later layer is post-classically monolingual Hebrew. I wish to express my thanks to Ronit Nikolsky and Arnon Atzmon with whom I consulted on these two post-classical corpora.

67 See van Bekkum, Hebrew liturgical poetry. The earliest liturgical poets (paytanim) were thus active in the period in which the redaction of the so called amoraic midrashim with their characteristic Hebrew-Aramaic bilingualism is assumed to have taken place. While there are Aramaic piyyutim and Aramaic elements in Hebrew piyyutim (see Elizur, Incorporation), the dominant language of Jewish liturgical poetry is Hebrew.

68 See Reeves, Trajectories, who refers to this literature as "post-rabbinic«.

69 Aramaic went on being used in prayer, in geonic responsa, and in post-talmudic halakhic genres. On Aramaic after the talmudic era, Breuer, Aramaic in Late Antiquity, 488, comments: »by virtue of its central position in talmudic literature, every scholar of this literature was familiar with Aramaic, and so the language continued to be known even after people no longer spoke it. In the medieval era it was a passive language known only from the ancient texts, yet to a limited extent it was also an active tongue, for the writers of Hebrew often integrated Aramaic into their writings."

70 On the process of institutionalisation of the rabbinic movement see Lapin, Rabbis as Romans, ch. 1. 
reflections on the early rabbinic "campaign for Hebrew « $^{71}$ and read as the expression of a preoccupation with a Jewish multilingualism to which several other rabbinic texts attest, this tradition may be described as internal metalinguistic evidence ${ }^{72}$ of an idealisation of Hebrew as monolingual mode of expression and as a precedent of the European "pro-Hebrew pressure of the ninth and tenth centuries.

The earliest document that, in using this tradition, insists on Hebrew as the language with which Jews once identified and with which, so the tacit claim, they should at least in writing go on identifying, is the halakhic midrash Mekhilta deRabbi Yishmael. In this first hermeneutic context, the tradition that praises Israel for having committed to their language in Egypt is transmitted as part of an exegetical statement that reads the demonyms ivryim and ha- ivry as references to the language of the people (MekhY Pischa 5). We could ascertain that the statement praising Israel's linguistic loyalty continued to be found »useful« in other exegetical contexts in corpora redacted during the Christian-Byzantine rule in Palestine. In this period the statement is somehow in conflict with other statements which acknowledge Jewish multilingualism as unproblematic, as for example, yMeg 1:11 (71b) par. MidTeh 31:7. Furthermore, the statement now praises loyalty to one original language in textual environments that are themselves bilingual.

WaR 32:5 and its parallels in other amoraic corpora maintain the constituents of the tannaitic statement but reorganise and reword them so that the new order can suit different exegetical-homiletical agendas. Here Israel's sexual morality and a certain anti-Hellenism appear to be weightier than linguistic attachment. We distinguished two actualisations of the tannaitic statement: Keeping their language was one of four things that saved the Israelites and made it possible for them to leave Egypt, one of four things that meant redemption for Israel (WaR 32:5, ShirR 4:12:1). We pointed out that while these texts suggest that the Exodus rewarded the maintenance of the Hebrew language in a foreign context, the commentary in MidTeh 114:4 is conspicuous for its ambiguity, in that it suggests both that the Israelites were saved because they spoke Hebrew, but also that they were saved so that they could speak Hebrew and be free from the people of foreign language.

In the final section we adduced a text in which Israel's purported loyalty to the original language is openly questioned (PesR 21:31), as well as two passages which echo the statement in late midrashic all-Hebrew contexts (PRE 48; SER 17). The significance of the tradition once it is transmitted in texts redacted entirely in Hebrew such as these should not be underestimated, for it now praises a conduct that characterises the authors of these works themselves, insofar as they define themselves by the very activity of writing in the original language of Israel. These texts and the broader Rehebraicisation - in the sense of a return to Hebrew in certain areas of the Jewish literary genre system ${ }^{73}$ - of which other works of late midrash, historiographical works, apocalypses, and piyyutim composed in Hebrew and the Hebrew inscriptions from southern Italy are evidence, may be seen as part of a response to a preoccupation that our tradition first addressed in the third century. ${ }^{74}$

72 We may add, given the scope of the surveyed texts, fragments of exegetical writings, that we have to do with micro-internal evidence.

73 This phenomenon runs parallel to the Arabicisation of the entire realm of Islam after the conquests of the seventh century. For both Rabbanite and Karaite Jews Arabic became a major literary language. See Maman, Karaite Hebrew.

74 See de Lange, Revival of the Hebrew language. 
The corpus perused in these pages tells us how, in the course of several centuries, some anonymous Jewish intellectuals of the stream of Judaism that became the orthodoxy, rabbinic Judaism, thought about the place of Hebrew as the Jewish language par excellence no matter where Jews live or what other languages are spoken or written there: as the language for a major communicative function (speech/discourse, study, prayer) and as the language to stay loyal to in order to stay Jewish, given that it was because of this language that the original redemption was possible in the first place - while this redemption is mentioned in connection with the Exodus it resonates throughout Israel's history of salvation and is the prototype for the eschatological redemption.

\section{Appendix: Hebrew Texts}

yMeg 1:11 (71b) (Vilna)

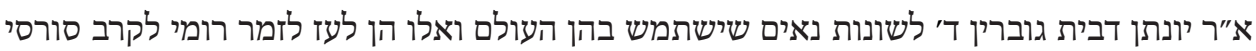

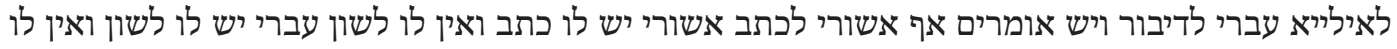

כתב

בחרו להם כתב אשורי ולשון עבר י כתב

MidTeh 31:7 (Buber)

אמר ר' יונתן ארבע לשונות הן, לשון רומי לקרב, לשון יוני לזמר, לשון פרסי לאלייה, לשון אשורית לתפלה, הוי תצפנם בסכה מריב לשונות.

SifDev 46 (Finkelstein)

ולמדתם אותם את בניכם, בניכם ולא בנותיכם דברי רבי יוסי בן עקיבה מיכן אמרו כשהתינוק מתחיל למדו לדבר

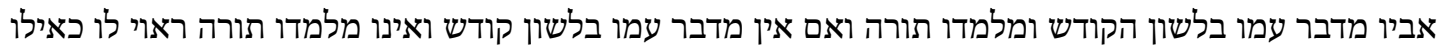

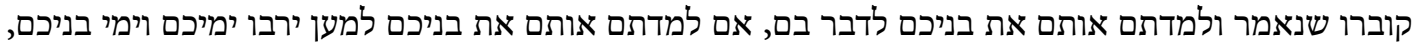

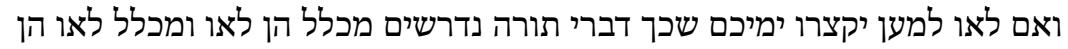

MekhY Pischa 5 (MS Oxford ${ }^{75}$ )

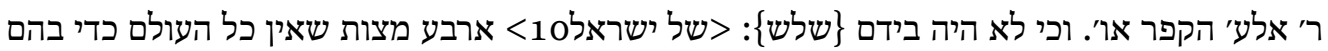
שלא נחשדו על העריות. ושלא נחשדו על לשון רע. ולא שינו את אל שמם. ולא ולא שינו את לשונם.

ומנין שלא חלפו לשונם. שנ' "מי שמך לאיש שר ושפט" וג' מיכן שהיו מדברים עברית. שנ' "כי פי המדבר אלי-

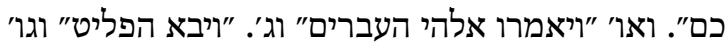

WayR 32:5 (Margulies)

ר' חונה בש' בר קפרא בשביל ארבעה דברים ניגאלו ישר' ממצרים, על ידי שלא שינו את שמן ולא שינו את

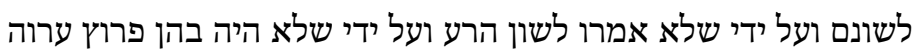

75 MS Oxford, Bodleian Library, 151. Quoted with kind permission of the Historical Dictionary Project of the Academy of the Hebrew Language. 
ShirR 4:12:1 (Vilna)

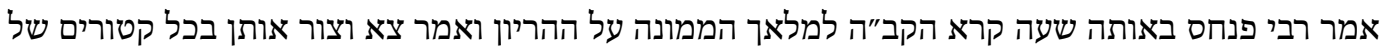

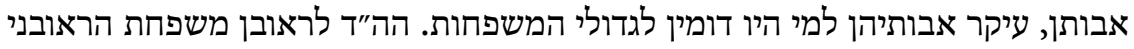

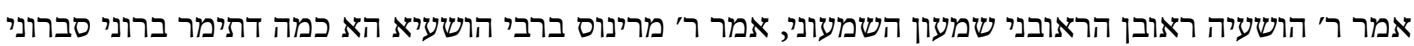

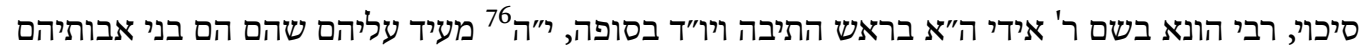

MidTeh 114:4 (Buber)

ולא שינו את לשונם, שהיו מספרים לשון הקודש, שנאמר בית יעקב מעם לועז היתה יהודה לקדשו, ללשון הקודש שלו.

PesR 21:31 (Ulmer)

רבי יהודה אמר אין לשון זה אנכי אלא לשון אהבה לשון חיבה, למלך ששילח את בנו למדינת הים ולמד לשון

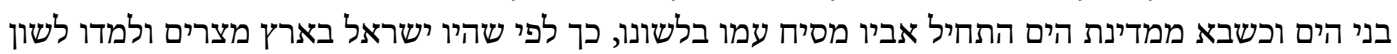

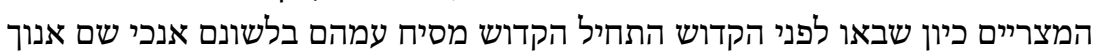

PRE 48 (Börner-Klein)

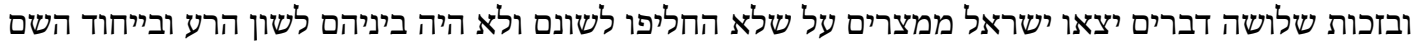

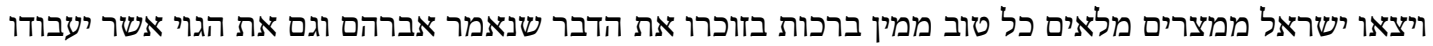

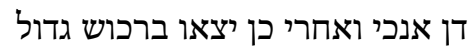

BamR 13:20 (Vilna)

ד"א למה נאמר ג' מינ' עולה כנגד ג' מדות טובות שהיו בידן של ישראל במצרים ובזכותן נגאלו שלא שינו

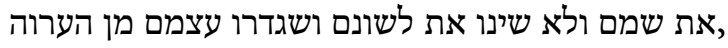

SER 17 (Friedmann)

ד"א בעטרה שעיטרה. כשהיו ישראל במדבר לא שינו שמם ולשונם. והיו מלאכי השרת מרננים אחריהם ואומ־

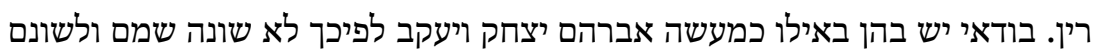

\section{Abbreviations}

BamR = Bamidbar Rabbah

EstR = Esther Rabbah

MekhY = Mekhilta deRabbi Yishmael

MidTeh $=$ Midrash Tehillim

PesRK = Pesiqta de-Rav Kahana

PesR = Pesiqta Rabbati

PRE = Pirqe de-Rabbi Eliezer

SER = Seder Eliyahu Rabbah

ShirR = Shir ha-Shirim Rabbah

76 The Vilna edition has the reading with the syntactic subject Yah, 
SivDev $=$ Sifre Devarim

TanB = Tanchuma Buber

WayR = Wayiqra Rabbah

yMeg $=$ Yerushalmi tractate Megillah

ySot $=$ Yerushalmi tractate Sotah 


\section{References}

Alexander, Philip, Using rabbinic literature as a source for the history of Late-Roman Palestine: Problems and issues, in: Martin Goodman and Philip Alexander (eds.), Rabbinic Texts and the History of Late Roman Palestine (Oxford, 2010) 7-24.

Appelbaum, Alan, The Rabbis' King-Parables: Midrash from the Third-Century Roman Empire (Piscataway, NJ, 2010).

Atzmon, Arnon, Midrashic traditions, literary editing, and polemics in Midrash Tehillim 22: Between Judaism and Christianity, Journal for the Study of Judaism 51 (2020) 97-124.

Atzmon, Arnon, The original order of Pesikta de-Rav Kahana, Journal of Jewish Studies 70 (2019) 1-23.

Bar-Asher, Moshe, Jewish languages and the Hebrew language, Journal of Jewish Languages 4 (2016) 125-140.

Bar-Asher Siegal, Elitzur A., Diglossia in rabbinic Hebrew, in: Geoffrey Khan (ed.), Encyclopedia of Hebrew Language and Linguistics 1 (Leiden, 2013) 725-729.

Beattie, D. R. G. and Philip R. Davies, What does Hebrew mean? Journal of Semitic Studies 56 (2011) 71-83.

Van Bekkum, Wout Jac., The Hebrew liturgical poetry of Byzantine Palestine: Recent research and perspectives, Prooftexts 28 (2008) 232-246.

Bonfil, Robert, History and Folklore in a Medieval Jewish Chronicle: The Family Chronicle of Ahima'az ben Paltiel (Leiden, 2009).

Breuer, Yochanan, Aramaic in Late Antiquity, in: Steven T. Katz (ed.), The Cambridge History of Judaism 4: The Late Roman-Rabbinic Period (Cambridge, 2006) 457-491.

Brody, Robert, Sa'adya Gaon. The Littman Library of Jewish Civilization (Oxford, 2013).

Bunis, David M. and James T. Robinson, Languages and translations, in: Robert Chazan (ed.), The Cambridge History of Judaism 6: The Middle Ages: The Christian World (Cambridge, 2018) 485-534.

Cordoni, Constanza, Seder Eliyahu: A Narratological Reading. Studia Judaica 100 (Berlin, 2018).

Dönitz, Saskia, Historiography among Byzantine Jews: The case of Sefer Yosippon, in: Robert Bonfil, Oded Irshai, Guy G. Stroumsa and Rina Talgam (eds.), Jews in Byzantium: Dialectics of Minority and Majority Cultures (Leiden, 2012) 951-968.

Elizur, Shulamit, The incorporation of Aramaic elements in ancient Palestinian piyyutim (Hebr.), Lešonenu 70 (2008) 331-328.

Fassberg, Steven E., What Semitic language did Jesus and other contemporary Jews speak? The Catholic Biblical Quarterly 72 (2012) 263-280.

Fraade, Steven D., Language mix and multilingualism in ancient Palestine: Literary and inscriptional evidence, Jewish Studies 48 (2012) 1-40.

Hary, Benjamin and Sarah Bunin Benor (eds.), Languages in Jewish Communities Past and Present. Contributions to the Sociology of Language 112 (Berlin, 2018).

Ilan, Tal, Lexicon of Jewish Names in Late Antiquity 2: Palestine 200-650 (Tübingen, 2012).

Ilan, Tal, Women quoting scripture in rabbinic literature, in: Tal Ilan, Ronit Nikolsky and Lorena Miralles-Maciá (eds.), Rabbinic Literature. Bible and Women 4/1 (Atlanta, forthcoming).

Kadari, Tamar, Shir ha-Shirim Rabbah: Synoptic Edition of the Midrash Shir ha-Shirim Rabbah. The Midrash Project, online, accessed on 25th May 2020: https://schechter.ac.il/ midrash/shir-hashirim-raba/. 
De Lange, Nicholas, Hebraists and Hellenists in the sixth-century synagogue: A new reading of Justinian's Novel 146, in: Constanza Cordoni and Gerhard Langer (eds.), Let the Wise Listen: Festschrift for Günter Stemberger on the Occasion of his 75th Birthday (Berlin, 2016) 217-226.

De Lange, Nicholas, The Hebrew language in the European diaspora, in: Benjamin Isaac and Aharon Oppenheimer (eds.), Studies on the Jewish Diaspora in the Hellenistic and Roman Periods (Tel Aviv, 1996) 111-137.

De Lange, Nicholas, The revival of the Hebrew language in the third century, Jewish Studies Quarterly 3 (1996) 342-358.

Lapin, Hayim, Rabbis as Romans: The Rabbinic Movement in Palestine, 100-40o CE (Oxford, 2012).

Maman, Aharon, Karaite Hebrew, in: Meira Polliack (ed.), Karaite Judaism: A Guide to its History and Literary Sources. Handbook of Oriental Studies, Section 1: The Near and Middle East 73 (Leiden, 2003) 485-503.

Mock, Keren, Hébreu: Du sacré au maternel (Paris, 2016).

Neusner, Jacob, Leviticus in Leviticus Rabbah, in: Jacob Neusner and Alan Avery-Peck, Encyclopedia of Midrash: Biblical Interpretation in Formative Judaism 1 (Leiden, 2005) 411429.

Neusner, Jacob, Pesiqta deRab Kahana: synagogue lections for special occasions, in: Jacob Neusner and Alan Avery-Peck (eds.), Encyclopedia of Midrash: Biblical Interpretation in Formative Judaism 2 (Leiden, 2005) 646-662.

Pirqe de-Rabbi Eliezer, ed. Dagmar Börner-Klein, Pirke de-Rabbi Elieser: Nach der Edition Venedig 1544 unter Berücksichtigung der Edition Warschau 1852. Studia Judaica 26 (Berlin, 2004).

Reeves, John C., Trajectories in Near Eastern Apocalyptic: A Postrabbinic Jewish Apocalypse Reader (Leiden, 2006).

Reif, Stefan and Elisabeth Hollender, Liturgy and Piyut, in: Robert Chazan (ed.), The Cambridge History of Judaism 6: The Middle Ages: The Christian World (Cambridge, 2018) 648-677.

Rutgers, Leonard V., Justinian's Novella 146 between Jews and Christians, in: Richard L. Kalmin and Schwartz, Seth (eds.), Jewish Culture and Society under the Roman Empire (Leuven, 2003), 385-407. Reprinted in Making Myths: Jews in Early Christian Identity Formation (Leuven, 2009) 49-77.

Sáenz-Badillos, Ángel, A History of the Hebrew Language (Cambridge, 1993).

Samely, Alex, Literary structures and historical reconstruction: The example of an amoraic Midrash, in: Martin Goodman and Philip Alexander (eds.), Rabbinic Texts and the History of Late Roman Palestine (Oxford, 2011) 185-216.

Seder Eliahu Rabba and Seder Eliahu Zuta, ed. Meir Friedmann, Seder Eliahu Rabba and Seder Eliahu Zuta (Tanna D'be Eliahu) (Vienna, 1902).

Silber, Michael K., The emergence of ultra-orthodoxy: The invention of a tradition, in: Jack Wertheimer (ed.), The Uses of Tradition: Jewish Continuity in the Modern Era (New York, 1992) 22-84.

Simonsohn, Shlomo, The Hebrew revival among early medieval European Jews, in: Saul Lieberman and Arthur Hyman (eds.), Salo Wittmayer Baron: Jubilee Volume on the Occasion of his Eightieth Birthday 2 (New York, 1974) 831-885.

Smelik, Willem F., Rabbis, Language and Translation in Late Antiquity (Cambridge, 2013). 
Sperber, Daniel, Rabbinic knowledge of Greek, in: Shmuel Safrai, Zeef Safrai, Joshua Schwartz and Peter J. Tomson (eds.), The Literature of the Sages 2: Midrash and Targum, Liturgy, Poetry, Mysticism, Contracts, Inscriptions, Ancient Science and the Languages of Rabbinic Literature. Compendia Rerum Iudaicarum ad Novum Testamentum 2/3/2 (Assen, 2006) 627-640.

Stemberger, Günter, Einführung in die Judaistik (Munich, 2002).

Stemberger, Günter, Einleitung in Talmud und Midrasch (Munich, 2011).

Stemberger, Günter, Hebräisch als ideale Sprache: Konsequenzen für die Hermeneutik, in: Judaica Minora 1: Biblische Traditionen im rabbinischen Judentum (Tübingen, 2010) 88102.

Stemberger, Günter, Mekhilta de-Rabbi Jishma'el: Ein früher Midrasch zum Buch Exodus (Berlin, 2010).

Stemberger, Günter, Midrashim zum Hohenlied und Geschichte Israels, in: Judaica Minora 1: Biblische Traditionen im rabbinischen Judentum (Tübingen, 2010) 248-255.

Stemberger, Günter, Mischna Avot, in: Judaica Minora 2: Geschichte und Literatur des rabbinischen Judentums (Tübingen, 2010) 317-330.

Tabori, Joseph and Arnon Atzmon, Esther Rabbah: Synoptic Edition. The Midrash Project, online, accessed on 25th May 2020: https://schechter.ac.il/midrash/esther_rabbah/.

Ulmer, Rivka, A Bilingual Edition of Pesiqta Rabbati I: Chapters 1-22. Studia Judaica 86 (Berlin, 2017).

Wagner, Esther-Miriam, Script-switching between Hebrew and Arabic scripts in documents from the Cairo Genizah, Intellectual History of the Islamicate World 7 (2019) 351-380.

Weinberger, Leon, Jewish Hymnography: A Literary History (London, 1998).

Weiss, Dov, Pious Irreverence: Confronting God in Rabbinic Judaism. Divinations: Rereading Late Ancient Religion (Philadelphia, 2017). 